\title{
Walking delay as leading symptom in late-onset Pompe disease
}

\author{
S Gökce*, N Karabul, A Herzog, E Mengel \\ From Proceedings of the 6th European Symposium: Steps Forward in Pompe Disease \\ Berlin, Germany. 23-24 November 2012
}

\section{Introduction}

Pompe disease is an autosomal recessive lysosomal storage disorder caused by a deficiency of the lysosomal enzyme acid $\alpha$-glucosidase. Clinical manifestations are dominated by progressive weakness of skeletal muscle in late-onset patients and by a combination of skeletal muscle weakness and hypertrophic cardiomyopathy in classic infantile patients.

\section{Results}

We retrospectively analyzed the prevalence of delayed motor milestones within the first 18 months of life in our Pompe cohort of 58 late-onset patients. Walking delay was recognized in $9 / 58$ patients. In $5 / 9$, loss of motor function was progressive and typically manifested in childhood. In $4 / 9$ patients, initial muscle weakness was not progressive. They reached all motor milestones and were able to hold these on ERT. The phenotypic childhood-onset patients weren't able to walk earlier than the 18th month of life, the rate of disease deterioration was faster, and they tended to have worse scores on the Walton \& Gardner-Medwin scale compared to the juvenile-onset patients. Despite the expectation of severe mutations in childhood-onset patients, some of them have the c.-32-13T>G mutation, but their disease progression was less rapid.

\section{Conclusion}

This assessment confirms that childhood-onset patients' first complaints are delayed walking and early abnormal gait. However, some patients with juvenile onset Pompe disease also present with delayed walking. Disease progression is slower in these patients compared to childhood-onset patients.

\footnotetext{
Villa Metabolica, Zentrum für Kinder- und Jugendmedizin der
} Universitätsmedizin, Mainz, Germany

C 2013 Gökce et al; licensee BioMed Central Ltd. This is an Open Access article distributed under the terms of the Creative Commons Attribution License (http://creativecommons.org/licenses/by/2.0), which permits unrestricted use, distribution, and reproduction in any medium, provided the original work is properly cited.
doi:10.1186/1471-2474-14-S2-P22

Cite this article as: Gökce et al: Walking delay as leading symptom in late-onset Pompe disease. BMC Musculoskeletal Disorders 2013 14(Suppl 2): P22.

Submit your next manuscript to BioMed Central and take full advantage of:

- Convenient online submission

- Thorough peer review

- No space constraints or color figure charges

- Immediate publication on acceptance

- Inclusion in PubMed, CAS, Scopus and Google Scholar

- Research which is freely available for redistribution 